\title{
PENGARUH MEDIA PEMBELAJARAN BERBASIS INFORMASI TEKNOLOGI (IT) TERHADAP PRESTASI BELAJAR FIQIH SISWA DI MADRASAH IBTIDAIYAH
}

\author{
Iffah Mukhlisah \\ Institut Islam Mamba'ul'Ulum (IIM) Surakarta \\ ifamukhlis85@gmail.com
}

\begin{abstract}
This study is intended to know: (1) the use of information technology (IT) Media (2) Fiqih achievement students. (3)The Interaction of the between learning media and Fiqih achievement. The method was used in this research is experiment method. The objets of this research are 40 students of Madrasah Ibtidaiyah in Sragen district that separated 20 students as experiment group, 20 students as control group. Data collecting method using questionnaire for the use of information technology (IT) media

, interview, documentation, observation and tes for Fiqih achievement. Data analysis technique using Liliefors for normalitas test and $y=a+b x$ for linier test. For correlation use product moment with significant 5\%.Based the result of research shows that there is an interaction between the effect of information technology (IT) Media and achievement in Fiqih $\left(F_{a b}>F_{\text {table }}\right.$ or 0,866>0,444), it can therefor said that hypothesis was accepted.
\end{abstract}

Keywords: media, information technology, achievement, fiqih

\section{Pendahuluan}

Pendidikan yang unggul adalah pendidikan yang mampu memenuhi kebutuhan masyarakat akansumber daya manusia yang berkualitas. Sekolah harus mampu meluluskan siswa-siswa yang mempunyai kompetensi sesuai jenjang pendidikan dan bidang jurusan. Pendidikan sekarang ini mengalami proses perubahan, dari yang bersifat tradisional berubah menjadi pendidikan milenial digital (Juwita:2018). Pembelajaran diarahkan memanfaatkan teknologi yang sedang berkembang, diharapkan lembaga pendidikan menjadi pencetak SDM yang berkualitas mampu mengikuti, mengenal, memanfaatkan dan menciptakan inovasi dibidang masing-masing dengan menggunakan bantuan teknologi.

Perkembangan pendidikan dan teknologi mempunyai hubungan yang cenderung berbanding lurus.Apabila perkembangan pendidikan baik, maka teknologi juga cenderung bisa dimanfaatkan dengan baik. Namun pada kenyataannya dilapangan, terutama di tingkat Madrasah Ibtidaiyah di Sragen, ratarata guru mengalami kendala dalam menciptakan ataupun memanfaatkan media yang berbasis teknologi.Sehingga penggunaan teknologi kurang maksimal sebagai alat bantu dalam memberikan materi pembelajaran.Banyak materi yang harus diajarkan guru kepada siswa, membuat guru mata pelajaran Fiqih kesulitan 
Dalam menyampaikan materi kepada siswa, karena pembahasannya seputar syariah tentang hukum khitan dan haid bagi jenjang kelas 5 MI (Depag, 2015:3).Seringkali yang dikeluhkan adalah materi yang masih banyak, namun waktu pembelajaran sudah berakhir; ataupun kalau materi tersampaikan tepat waktu, namun kedalaman pemahaman mata pelajaran oleh siswa sangat rendah.

Salah satu bentuk alat bantu yang bisa dimanfaatkan dalam mengajarkan mata pelajaran Fiqih yaitu Media pembelajaran berbasiskan IT yang bisa dikemas dengan menarik. Penggunaan media pembelajaran yang up to date diharapkan mampu meningkatkan kualitas pembelajaran Fiqih, baik dari pihak guru maupun siswa.Media yang dipandang lebih modern dan mutakhir salah satunya adalah komputer, seperti pernyataan Seels dan Glasgow (dalam Arsyad, 2002:3) yang membagi media ke dalam dua kelompok besar, yaitu: media tradisional dan media teknologi mutakhir. Pilihan media tradisional berupa media visual diam tak diproyeksikan dan yang diproyeksikan, audio, penyajian multimedia, visual dinamis yang diproyeksikan, media cetak, permainan, dan media realia. Sedangkan pilihan media teknologi mutakhir berupa media berbasis telekomunikasi (misal teleconference) dan media berbasis mikroprosesor (misal: permainan komputer dan hypermedia).

Banyaknya pilihan berbagai jenis media yang ada sekarang ini membuat guru mempunyai banyak pilihan dalam menggunakan media mana yang akan dipakai dalam proses pembelajaran sesuai dengan kebutuhannya. Sehingga guru dituntut mampu mengelola penggunaan media dengan baik.Pengelolaan yang baik adalah salah satu indikator keberhasilan pendidikan (Dali, 2017: 99).Salah satu faktor yang mempengaruhi ketrampilan guru dalam pengelolaan media adalah guru yang mampu menggunakan media kekinian sesuai dengan kemajuan teknologi.

Penggunaan media berbasis IT terutama komputer dirasakan masih belum maksimal, penggunaan komputer biasanya hanya seputar sebagai alat bantudalam menanyangkan video ataupun slide materi dalam bentuk power point. Komputer secara umum masih belum digunakan sebagai alat penyusun program pembelajaran yang terintegrasi antara guru, siswa, dan orang tua.Selain itu durasi penggunaan komputer masih terbilang rendah, karena guru lebih banyak 
mengandalkan materi ringkasan di lembar kerja siswa (LKS) yang cenderung lebih praktis, mudah dan ringan dibawa kemana-mana.Pembelajaran yang memanfaatkan teknologi bagi guru mempunyai berbagai keunggulan, antara lain:

(1) memperluas background knowledge guru; (2) Pembelajaran lebih dinamis dan fleksibel; (3) mengatasi keterbatasan bahan ajar atau sumber belajar; (4) kontribusi dan pengayaan bahan ajar atau sumber belajar; dan (5) Implementasi Student Active Learning (SAL), CBSA, dan PAKEM (Rusman, 2011: 57). Namun, pengaruh di lingkungan sekitar guru mempengaruhi cara kerja guru dalammemanfaatkan media komputer. Seperti kurangnya dorongan dari kepala madrasah dalam memanfaatkan teknologi, rekan sejawat guru yang cenderung acuh terhadap teknologi dalam pembelajaran, rendahnya kualitas sarana prasarana pendukung pembelajaran, serta tingkat sumber daya yang dimiliki guru dalam mengoperasionalkan komputer.Apabila dari pihak guru saja ada banyak kekurangan dalam memanfaatkan komputer untuk pembelajaran, hal ini secara otomatis juga berpengaruh pada intensitas keaktifan siswa dalam memanfaatkan komputer.

Siswa akan mulai terbiasa menggunakan komputer, apabila tugas yang diberikan oleh guru juga menuntut siswa untuk menggunakan komputer. Selama ini permasalahan yang dihadapi oleh siswa adalah intensitas yang rendah dalam memanfaatkan komputer dalam memperdalam materi-materi pelajaran yang diberikan oleh guru.Pada mata pelajaran khusus TIK mereka cenderung dihadapkan pada teori-teori, dan sedikit porsinya dalam praktek.Sehingga tidak heran ketika komputer atau laptop yang dimiliki oleh siswa dirumah kurang dimanfaatkan dengan baik oleh siswa dalam membantu mereka belajar.Komputer bagi mereka cenderung sebagai alat untuk memutar video dan bermain game.Kondisi ini kontra dengan tujuan dalam mempelajari TIK, antara lain: (1) mengembangkan kemampuan belajar berbasis Teknologi Informasi dan Komunikasi, sehingga proses pembelajaran lebih optimal, menarik dan mendorong siswa terampil dalam berkomunikasi, terampil mengorganisasi informasi, dan terbiasa bekerjasama; (2) mengembangkan kemampuan belajar mandiri, berinisiatif, inovatif, kreatif dan bertanggung jawab dalam penggunaan Teknologi Informasi dan Komunikasi untuk pembelajaran, bekerja dan pemecahanmasalah sehari-hari(Media diknas, 2019). 
Penelitian tentang pemanfaatan media yang berbasiskan teknologi ini akan dapat menggali berbagai informasi, anatara lain tentang: (1) tinggi rendahkan pemanfaatan media pembelajaran berbasis IT oleh siswa; (2) tingkat prestasi belajar siswa tentang mata pelajaran fiqih; dan (3) bagaimana keterkaitan pola antara media pembelajaran berbasis IT dengan prestasi belajar fiqih siswa madrasah. Hasil dari penelitian ini nantinya diharapkan mampu menjadi salah satu referensi dan acuan bagi guru dalam mengaplikasikan teknologi kompuer dalam pembelajaran di kelas.Selain itu, dari sudut pandang siswa, diharapkan menjadi pemacu dalam membantu untuk memahami materi yang mungkin belum didapatnaya di kelas.

Metode yang digunakan dalam penelitian ini adalah metode eksperimen (post-test-only control design) (Sugiyono, 2008: 82). Objek kajian penelitian ini akan terbagi menjadi 2 kelompok, yaitu kelompok yang diberikan eksperimen berupa perlakuan penggunaan media pembelajaran berbasis IT dan media digital; dan kelompok kontrol, yaitu kelompok yang tidak diberikan perlakuan. Ragam Variabel Penelitian eksperimental terdiri atas dua variabel: Variabel bebas (X) yaitu media pembelajaran berbasis IT dan digital dan variabel terikat (Y), yaitu prestasi belajar Fiqih. Penelitian ini berusaha mengetahui interaksi antara media pembelajaran terhadap prestasi belajar Fiqih di MI Madrasah Ibtidaiyah Swasta (MIS) Taraman dan Madrasah Ibtidaiyah Negeri (MIN) 9 sragen, masing-masing diambil 20 siswa sebagai sampel penelitian.

Dalam mengambil sampel penulis menggunakan teknik proportionate stratified Random Sampling, teknik ini dipakai karena populasi MI di kabupaten Sragen mempunyai beberapa unsur yang tidak homogen dan berstrata secara proporsional. Pengumpulan data penelitian ini dilakukan dengan: pertama, wawancaradengan kepala madrasah, para guru, siswa dan beberapa perwakilan dari orang tua siswa. Kedua, observasiuntuk memperoleh data tentang kondisi tentang MIM Taraman Sidoharjo dan di MIN 9 Sragen.Ketiga,angket untuk memperoleh data tentang penggunaan media pembelajaran berbasiskan IT dan digital bagi siswa.Keempat, dokumentasi, digunakan untuk memperoleh data tentang beberapa data seperti struktur organisasi, data guru, data siswa, kurikulum, visi misi serta prestasi belajar mata pelajaran fiqih. 
Teknik analisis data dilakukan dengan: pertama, uji normalitas, berfungsi untuk mengetahui apakah populasi data berdistribusi normal atau tidak. Pada penelitian ini menggunakan uji normalitas Liliefors.Kedua, uji linier, untuk mengetahui apakah antara variabel mempunyai hubungan linier atau tidak. Uji linier menggunakan rumus $\mathrm{y}=\mathrm{a}+\mathrm{bx}$. Ketiga, uji signifikasi koefisien korelasi (product moment). Dari penelitian ini diambil dua kemungkinan hipotesis yang diajukan adalah:

$\mathrm{H}_{0}$ : media pembelajaran berbasis ITberpengaruh terhadap prestasi belajar fiqih siswa MIS Taramandan MIN 9 Sragen. $\mathrm{H}_{1}$ : media pembelajaran berbasis ITtidak berpengaruh terhadap prestasi belajar fiqih siswa MISTaraman dan MIN 9 Sragen.

\section{Pembahasan}

Dari Penelitian dan pengumpulan data diperoleh data tentang penggunaan Media Pembelajaran berbasis IT dan Digital, berupa penyebaran angket kepada siswa:

Tabel 1

Data Skor Pengguanan Media Berbasis IT

\begin{tabular}{cc}
\hline $\begin{array}{c}\text { No } \\
\text { Responden }\end{array}$ & Skor Total \\
\hline 1 & 70 \\
\hline 2 & 65 \\
\hline 3 & 60 \\
\hline 4 & 70 \\
\hline 5 & 70 \\
\hline 6 & 70 \\
\hline 7 & 75 \\
\hline 8 & 76 \\
\hline 9 & 75 \\
\hline 10 & 76 \\
\hline 11 & 75 \\
\hline 12 & 80 \\
\hline 13 & 80 \\
\hline 14 & 83 \\
\hline 15 & 81 \\
\hline 16 & 84 \\
\hline 17 & 86 \\
\hline 18 & 85 \\
\hline
\end{tabular}




\begin{tabular}{cc}
19 & 87 \\
\hline 20 & 84 \\
\hline rata-rata & 76,6 \\
\hline
\end{tabular}

Data ini diambil dari proses pengumpulan data berupa penyebaran angket kepada kelompok siswa yang diberikan treatment atau perlakuan. Treatment yang diberikan adalah guru menggunakan media berbasis IT dalam mengajarkan mata pelajaran fiqih di dalam kelas, dari sebelumnya yang tidak menggunakan media tersebut. Pemilihan media pengajaran berupa media yang berbasis IT atau pada kasus ini lebih dekat kepada penggunaan komputer dalam membantu menjelaskan, menyampaikan dan menguraikan materi yang mungkin belum tersampaikan oleh guru kepada siswa.

Pada era digital milenial ini penggunaan komputer/laptop adalah hal yang sangat umum dan dipandang sangat penting sekali dalam setiap kegiatan dan aktivitas manusia, termasuk salah satunya adalah dibidang pendidikan.Pembelajaran dengan menggunakan komputer dibedakan menjadi 2 kategori penerapan, antara lain (Rusman, 2011:97): (1) Computer Assisted Instruction (CAI) adalah proses pembelajaran yang memanfaatkan komputer sebagai alat bantuan. Perangkat lunak komputer berfungsi membantu guru dalam proses pembelajaran, seperti multimedia, alat bantu presentasi, demonstrasi dan alat bantu dalam kegiatan pembelajaran; (2) Computer Based Instruction (CBI), adalah proses pembelajaran yang berbasis kompuer, dimana computer berfungsi sebagai perangkat pembelajaran. Dimana bisa dikatakan bahwa pembelajaran bisa dilakukan secara individual sebagai kelanjutan proses pembelajaran di kelas dengan menerapkan pembelajaran tuntas (mastery learning).

Pada penelitian ini arah penggunaan komputer cenderung ke model CBI bagi siswa, sedangkan bagi guru lebih ke arah model CAI. Hal ini dikarenakan pada proses pembelajaran di kelas,guru memanfaatkan komputer sebagai perangkat dan alat bantu dalam menjelaskan materi fiqih yang belum di pahami oleh siswa. Intensitas penggunaannyapun juga tidak terlalu banyak di kelas, sehingga siswa cenderung secara mandiri juga menggunakan komputer dalam mengejar materi yang belum dipahami di dalam kelas sampai menemukan pemahaman yang dicari. Kecepatan dalam penyerapan materi masing-masing siswa akan berbeda-beda. Pada 
pola pembelajaran seperti ini menunjukkan ciri pembelajaran tuntas bagi siswa dengan mempertimbangkan perbedaan karakteristik individual siswa.

Objek penelitian ini adalah siswa, sehingga materi angket penggalian informasi tentang data penggunaan media berbasis IT bagi siswa.Angket tersebut di bagi kepada siswa untuk diisi oleh siswa sendiri. Isi materi angket diantaranya berupa: penggunaan komputer dalam membantu tugas sekolah, durasi dalam penggunaan komputer, tingkat pemahaman siswa terhadap materi pelajaran dengan CD interaktif dan sebagainya.

Angket yang digunakan adalah angket model Likert, dimana cara kerjanya menggunakan metode rating(Azwar, 2011:138). Pendekatan dengan skala Likert ini tidak memerlukan adanya kelompok panel penilai (judging group), tetapi nilai skala sikap ditentukan distribusi respon pada masing-masing pilihan dengan option : Sangat Sering Sekali (SSS), Sering Sekali (SS), Sering (S), Jarang (J) dan Sangat Jarang (SJ). Masing-masing option sudah ditentukan nilainya, sehingga nilai penggunaan media berbasis IT diambil dari nilai angket yang diisi siswa sebagai responden penelitian ini.

Kemudian hasilnya diadobsi dalam bentuk tabel, nama responden disamarkan dengan nomor urut responden, untuk menghindari subjektivitas penilaian. Dari penyebaran angket diperoleh data paling rendah adalah 60, sedangkan yg paling tinggi adalah 87 , sedangkan rata-rata diperoleh nilai 76,6 . Dari data tersebut peneliti memasukkan ke dalam tiga kategori rendah antara rank rata- rata 30-59 rendah, 60-79 menengah, 80-100 tinggi. Sehingga dengan nilai rata-rata 76,6 bisa dikatakan pemanfaatan dan penggunaan media belajar berbasis IT masuk kategori sedang.

Tabel 2

Prestasi Belajar Fiqih Kelas Kontrol

\begin{tabular}{cc}
\hline $\begin{array}{c}\text { No } \\
\text { Responden }\end{array}$ & Fiqih \\
\hline 1 & 70 \\
\hline 2 & 75 \\
\hline 3 & 75 \\
\hline 4 & 76 \\
\hline 5 & 80 \\
\hline 6 & 78 \\
\hline 7 & 70 \\
\hline
\end{tabular}




\begin{tabular}{cc}
\hline 8 & 75 \\
\hline 9 & 74 \\
\hline 10 & 73 \\
\hline 11 & 80 \\
\hline 12 & 72 \\
\hline 13 & 70 \\
\hline 14 & 72 \\
\hline 15 & 72 \\
\hline 16 & 75 \\
\hline 17 & 75 \\
\hline 18 & 68 \\
\hline 19 & 65 \\
\hline 20 & 78 \\
\hline Rata-rata & 73,7 \\
\hline
\end{tabular}

Tabel di atas menunjukkan nilai hasil prestasi belajar fiqih siswa kelas kontrol, sebanyak 20 siswa. Pengambilan data kelas kontrol tersebut menggunakan tes tertulis materi fiqih kelas 5 MI, yang kemudian ditabulasikan ke dalam bentuk tabel. Dari sejumlah siswa tersebut nilai terendah adalah 65, nilai tertinggi adalah 80. Siswa yang mendapatkan nilai 65 sejumlah 1 orang; nilai 68 sejumlah 1 orang; nilai 70 sejumlah 3 orang; nilai 72 sejumlah 3 orang, nilai 73 sejumlah 1 orang, nilai 74 sejumlah 1 orang; nilai 75 sejumlah 5 orang; nilai 76 sejumlah 1 orang; nilai 78 sejumlah 2 orang dan nilai 80 sejumlah 2 orang. Dari data tersebut peneliti memasukkan ke dalam tiga kategori rendah antara rank rata-rata 30-59 rendah, 6079 menengah, 80-100 tinggi. Sehingga dengan nilai rata-rata 73,7 bisa dikatakan hasil belajar mata pelajaran fiqih di kelas control masuk kategori sedang.

Tabel 3

Prestasi Belajar Fiqih Kelas Eksperimen

\begin{tabular}{cc}
\hline $\begin{array}{c}\text { No } \\
\text { Responden }\end{array}$ & Fiqih \\
\hline 1 & 81 \\
\hline 2 & 80 \\
\hline 3 & 82 \\
\hline 4 & 80 \\
\hline 5 & 80 \\
\hline 6 & 82 \\
\hline 7 & 84 \\
\hline 8 & 85 \\
\hline 9 & 84 \\
\hline
\end{tabular}




\begin{tabular}{cc}
\hline 10 & 84 \\
\hline 11 & 86 \\
\hline 12 & 85 \\
\hline 13 & 85 \\
\hline 14 & 86 \\
\hline 15 & 85 \\
\hline 16 & 86 \\
\hline 17 & 90 \\
\hline 18 & 87 \\
\hline 19 & 88 \\
\hline 20 & 90 \\
\hline Rata-rata & 84,5 \\
\hline
\end{tabular}

Tabel no 3 menunjukkan data prestasi belajar fiqih pada kelas eksperimen, yaitu kelas yang diberi perlakuan berupa pembelajaran dengan media berbasis IT. Metode penggambilan data dan jenis soal sama dengan kelas kontrol, yaitu menggunakan metode tes secara tertulis kepada siswa. Kemudian data dimasukkan ke dalam tabel prestasi belajar fiqih kelas eksperimen.Nilai terendah adalah 80 dan nilai tertinggi adalah 90. Siswa yang mendapat nilai 80 sejumlah 3siswa, nilai 81 sejumlah 1 siswa, nilai 82 sejumlah 2 orang, nilai 84 sejumlah 3 oraang, nilai 85 sejumlah 4 orang, nilai 86 sejumlah 3 orang, nilai 87 sejumlah 1 orang, nilai 88 sejumlah 1 orang, nilai 90 sejumlah 2 orang. Rata-rata nilai prestasi belajar fiqih di kelas eksperimen adalah 84,5. Dari data tersebut peneliti memasukkan ke dalam tiga kategori rendah antara rank rata-rata 30-59 rendah, 60-79 menengah, 80-100 tinggi. Sehingga dengan nilai rata-rata 73,7 bisa dikatakan hasil belajar mata pelajaran fiqih di kelas eksperimen masuk kategori tinggi.

Dari data prestasi belajar fiqih pada tabel no 2 dan 3, terlihat sekali perbedaan awal antara kelas kontrol dan kelas eksperimen. Kelas kontrol masuk ke dalam kategori sedang, di sisi lain kelas eksperimen masuk ke dalam kategori tinggi.Analisis data-data tersebut menunjukkan bahwa penggunaan media berbasisi IT oleh guru disekolah dan kemudian dilanjutkan dengan belajar mandiri oleh siswa di rumah dengan bantuan komputer, bisa menstimulus kemampuan belajar siswa.Karena pada hakikatnya salah satu fungsi media pembelajaran adalah mampu menjelaskan materi-materi yang mungkin belum tersampaikan guru kepada siswa di saat pembelajaran di kelas (Sanaky, 2015:6-7). 
Selain itu komputer merupakan media yang sangat fleksibel, bisa dipelajari kapan saja tanpa terpaku pada batas ruang dan waktu.Komputer juga mampu merekam aktivitassiswa selama menggunakan program pembelajaran, member kesempatan lebih baik untuk pembelajaran secara perorangan dan perkembangan setiap siswa selalu dapat dipantau.Kendali pembelajaran dengan computer berada di tangan siswa, sehingga tingkat kecepatan belajar siswa dapat disesuaikan dengan tingkat penguasaannyaArsyad (2002:54-55).Model media seperti ini baik sekali diterapkan pada pembelajaran yang bersifat mandiri, total, dan menghargai perbedaan individual.Data tentang Penggunaan Media Berbasis IT dan Digital, serta tentang prestasi belajar Fiqih dijadikan dasar untuk mencari koefisien korelasional.

Tabel 4.

Tabel data Hasil Penelitian Uji Normalitas Penggunaan Media Berbasis IT

\begin{tabular}{ccccrc}
\hline $\begin{array}{c}\text { No } \\
\text { Responden }\end{array}$ & $\begin{array}{c}\text { Skor } \\
\text { Total }\end{array}$ & Zi skor & $\mathbf{F}(\mathbf{Z i})$ & $\mathbf{S}(\mathbf{Z i})$ & $|\mathbf{F}(\mathbf{Z i})-\mathbf{S}(\mathbf{Z i})|$ \\
\hline 1 & 70 & -0.886640975 & 0.187636113 & 0.05 & 0.137636113 \\
\hline 2 & 65 & -1.558338684 & 0.059576492 & 0.1 & 0.040423508 \\
\hline 3 & 60 & -2.230036392 & 0.012872513 & 0.15 & 0.137127487 \\
\hline 4 & 70 & -0.886640975 & 0.187636113 & 0.2 & 0.012363887 \\
\hline 5 & 70 & -0.886640975 & 0.187636113 & 0.25 & 0.062363887 \\
\hline 6 & 70 & -0.886640975 & 0.187636113 & 0.3 & 0.112363887 \\
\hline 7 & 75 & -0.214943267 & 0.414905776 & 0.35 & 0.064905776 \\
\hline 8 & 76 & -0.080603725 & 0.467878552 & 0.4 & 0.067878552 \\
\hline 9 & 75 & -0.214943267 & 0.414905776 & 0.45 & 0.035094224 \\
\hline 10 & 76 & -0.080603725 & 0.467878552 & 0.5 & 0.032121448 \\
\hline 11 & 75 & -0.214943267 & 0.414905776 & 0.55 & 0.135094224 \\
\hline 12 & 80 & 0.456754442 & 0.676076223 & 0.6 & 0.076076223 \\
\hline 13 & 80 & 0.456754442 & 0.676076223 & 0.65 & 0.026076223 \\
\hline 14 & 83 & 0.859773067 & 0.805042926 & 0.7 & 0.105042926 \\
\hline 15 & 81 & 0.591093983 & 0.722771275 & 0.75 & 0.027228725 \\
\hline 16 & 84 & 0.994112609 & 0.839915976 & 0.8 & 0.039915976 \\
\hline 17 & 86 & 1.262791692 & 0.896667974 & 0.85 & 0.046667974 \\
\hline 18 & 85 & 1.12845215 & 0.870435493 & 0.9 & 0.029564507 \\
\hline 19 & 87 & 1.397131234 & 0.918812945 & 0.95 & 0.031187055 \\
\hline 20 & 84 & 0.994112609 & 0.839915976 & 1 & 0.160084024 \\
\hline
\end{tabular}

Uji normalitas merupakan syarat utama yang harus dilakukan dalam statistik parametrik regresi dan Anova merupakan.Kegiatan tersebut bertujuan untuk menguji apakah dalam model regresi, variabel penggangu memiliki distribusi normal. Jika 
asumsi ini dilanggar, maka uji statistik menjadi tidak valid atau bias terutama untuk sampel kecil. Uji normalitas dapat dilakukan melalui dua pendekatan yaitu melalui pendekatan grafik (histogram dan P-P Plot) atau uji kolmogorov-smirnov, chi-square, Liliefors maupun Shapiro-Wilk.Pada penelitian ini digunakan uji normalitas dengan pendekatan yang digunakan Liliefors.

Pada penelitian ini data tentang penggunaan media berbasis IT, kemudian diuji normalitas. Pengujian tersebut untuk mencari tahu, apakah data yang didapat tersebut berdistribusi normal apa tidak. Dari perhitungan dengan menggunakan bantuan program excel di dapat hasil $\mathrm{L}$ hitung $=0,16$ dan $\mathrm{L}$ tabel $=0,19$ dengan $\mathrm{N}=20$.Prinsip hipotesis data uji normalitas adalah, apabila L hitung itu nilainya lebih sedikit dari padaL tabel maka bisa dikatakan data berdistribusi normal. Sebaliknya apabila L hitung itu nilainya lebih besar dari pada L tabel maka bisa dikatakan data tidak berdistribusi normal. Karena pada perhitungan ini di dapat hasil akhir L hitung $<\mathrm{L}$ tabel, $\mathrm{L}$ hitung $=0,16<\mathrm{L}$ tabel $=$ 0,19, maka Data dikatakan berdistribusi normal bisa.

Tabel 5.

Tabel data Uji Normalitas Prestasi Belajar Fiqih

\begin{tabular}{ccccrr}
\hline $\begin{array}{c}\text { No } \\
\text { Responden }\end{array}$ & $\begin{array}{c}\text { Skor } \\
\text { Total }\end{array}$ & Zi skor & $\mathbf{F}(\mathbf{Z i})$ & $\mathbf{S}(\mathbf{Z i})$ & $|\mathbf{F}(\mathbf{Z i})-\mathbf{S}(\mathbf{Z i})|$ \\
\hline 1 & 81 & -1.159903325 & 0.123044084 & 0.05 & 0.073044084 \\
\hline 2 & 80 & -1.491304275 & 0.067940814 & 0.1 & 0.032059186 \\
\hline 3 & 82 & -0.828502375 & 0.203693025 & 0.15 & 0.053693025 \\
\hline 4 & 80 & -1.491304275 & 0.067940814 & 0.2 & 0.132059186 \\
\hline 5 & 80 & -1.491304275 & 0.067940814 & 0.25 & 0.182059186 \\
\hline 6 & 82 & -0.828502375 & 0.203693025 & 0.3 & 0.096306975 \\
\hline 7 & 84 & -0.165700475 & 0.434196336 & 0.35 & 0.084196336 \\
\hline 8 & 85 & 0.165700475 & 0.565803664 & 0.4 & 0.165803664 \\
\hline 9 & 84 & -0.165700475 & 0.434196336 & 0.45 & 0.015803664 \\
\hline 10 & 84 & -0.165700475 & 0.434196336 & 0.5 & 0.065803664 \\
\hline 11 & 86 & 0.497101425 & 0.690441235 & 0.55 & 0.140441235 \\
\hline 12 & 85 & 0.165700475 & 0.565803664 & 0.6 & 0.034196336 \\
\hline 13 & 85 & 0.165700475 & 0.565803664 & 0.65 & 0.084196336 \\
\hline 14 & 86 & 0.497101425 & 0.690441235 & 0.7 & 0.009558765 \\
\hline 15 & 85 & 0.165700475 & 0.565803664 & 0.75 & 0.184196336 \\
\hline 16 & 86 & 0.497101425 & 0.690441235 & 0.8 & 0.109558765 \\
\hline 17 & 90 & 1.822705224 & 0.965825976 & 0.85 & 0.115825976 \\
\hline 18 & 87 & 0.828502375 & 0.796306975 & 0.9 & 0.103693025 \\
\hline 19 & 88 & 1.159903325 & 0.876955916 & 0.95 & 0.073044084 \\
\hline 20 & 90 & 1.822705224 & 0.965825976 & 1 & 0.034174024 \\
\hline
\end{tabular}


Selain menguji data penggunaan media pembelajaran berbasis IT, data prestasi belajar fiqih juga diuji tingkat normalitasnya. Perhitungan uji normalitas ini nanti juga akan menunjukkan, bahwa data tetang prestasi pembelajaran fiqih apakah berdistribusi normal apa tidak. Penyebaran data bisa dikatakan normalbiasanya dipengaruhi oleh beberapa faktor, antara lain:(1) banyak sedikitnya jumlah sampel ataupun objek yang diteliti, (2) data penelitian yang ekstrem, (3)kurangnya data diskriminasi, (4) pengurutan data, (5) data mendekati nilai nol (Setiawan, 2019).

Dari perhitungan dengan menggunakan bantuan program excel di dapat hasil $\mathrm{L}$ hitung $=0,18$ dan $\mathrm{L}$ tabel $=0,19$ dengan $\mathrm{N}=20$. Prinsip hipotesis data uji normalitas adalah, apabila L hitung itu nilainya lebih sedikit dari pada L tabel maka bisa dikatakan data berdistribusi normal. Sebaliknya apabila L hitung itu nilainya lebih besar dari pada L tabel maka bisa dikatakan data tidak berdistribusi normal. Karena pada perhitungan ini di dapat hasil akhir $\mathrm{L}$ hitung $<\mathrm{L}$ tabel, $\mathrm{L}$ hitung $=0,18<\mathrm{L}$ tabel $=0,19$, maka Data dikatakan berdistribusi normal bisa.

Tabel 6

Uji Linier variabel (X) dan Variabel (Y)

\begin{tabular}{|c|c|c|c|c|}
\hline $\begin{array}{c}\text { No } \\
\text { Responden }\end{array}$ & $\begin{array}{l}\text { Media IT } \\
\quad(\mathrm{X})\end{array}$ & $\begin{array}{c}\text { Prestasi } \\
\text { Belajar } \\
\text { Fiqih (Y) }\end{array}$ & XY & $\mathrm{X}^{2}$ \\
\hline 1 & 70 & 65 & 4550 & 4900 \\
\hline 2 & 65 & 65 & 4225 & 4225 \\
\hline 3 & 60 & 70 & 4200 & 3600 \\
\hline 4 & 70 & 65 & 4550 & 4900 \\
\hline 5 & 70 & 70 & 4900 & 4900 \\
\hline 6 & 70 & 74 & 5180 & 4900 \\
\hline 7 & 75 & 70 & 5250 & 5625 \\
\hline 8 & 76 & 73 & 5548 & 5776 \\
\hline 9 & 75 & 73 & 5475 & 5625 \\
\hline 10 & 76 & 75 & 5700 & 5776 \\
\hline 11 & 75 & 78 & 5850 & 5625 \\
\hline 12 & 80 & 80 & 6400 & 6400 \\
\hline 13 & 80 & 82 & 6560 & 6400 \\
\hline 14 & 83 & 80 & 6640 & 6889 \\
\hline 15 & 81 & 80 & 6480 & 6561 \\
\hline 16 & 84 & 82 & 6888 & 7056 \\
\hline 17 & 86 & 80 & 6880 & 7396 \\
\hline 18 & 85 & 82 & 6970 & 7225 \\
\hline
\end{tabular}




\begin{tabular}{rcccc}
\hline 19 & 87 & 85 & 7395 & 7569 \\
\hline 20 & 84 & 84 & 7056 & 7056 \\
\hline Sum $=$ & 1532 & 1513 & 118404 & 115271 \\
\hline Rata2 $=$ & 76.6 & 75.65 & 5920.2 & 5763.55 \\
\hline
\end{tabular}

Selain diuji dengan distribusi normalitas, data tersebut juga diuji tingkat linieritas.Tujuannya sdalah untuk mengetahui tingkat linieritas dari antara penggunaan media berbasis IT dengan prestasi belajar fiqih. Uji linier menggunakan rumus persamaan regresi dua baris yaitu $: y=a+b x$. Data $X$ mewakili media berbasis IT dan data Y mewakili prestasi belajar. Dari tabel tersebut menunjukkan bahwa jumlah $\mathrm{X}$ adalah 1532 dengan rata-rata 76,6; data prestasi belajar Y jumlah 1513 dengan rata-rata75,65; data XY jumlah 118404 dengan rata-rata 5920,2 dan $\mathrm{X}^{2}$ jumlah 115271 dengan rata-rata 5763,55.

Hasil tersebut dimasukkan

$\mathrm{a}=\mathrm{Y}-\mathrm{bX}$

$a=75,65-0,761018237(76,6)$

$a=75,5-58,29399696$

$a=17,356$

Hasil tersebut kemudian dimasukkan ke dalam rumus persamaan garis regresi $y=a+b x$

Persamaan yang di dapat :

$\mathrm{Y}=17,536+0,761018237$ ( $\mathrm{x})$

$\mathrm{Y}=$ Penggunaan Media Berbasis IT dan Digital

$\mathrm{X}=$ Prestasi belajar Fiqih

Nilai a $=17,536$

Nilai $b=0,761$

Dari perhitungan tersebut dapat disimpulkan kedua varibel X dan Y mempunyai hubungan yang linier.

Tabel 7

Uji Koefisien Korelasi Antara Variabel $(\mathrm{X})$ variabel $(\mathrm{Y})$

\begin{tabular}{cccccc}
\hline No Resp & $\mathbf{X}$ & $\mathbf{Y}$ & $\mathbf{X 2}$ & $\mathbf{Y 2}$ & $\mathbf{X Y}$ \\
\hline 1 & 70 & 65 & 4900 & 4225 & 4550 \\
\hline 2 & 65 & 65 & 4225 & 4225 & 4225 \\
\hline 3 & 60 & 70 & 3600 & 4900 & 4200 \\
\hline 4 & 70 & 65 & 4900 & 4225 & 4550 \\
\hline
\end{tabular}




\begin{tabular}{cccccc}
\hline 5 & 70 & 70 & 4900 & 4900 & 4900 \\
\hline 6 & 70 & 74 & 4900 & 5476 & 5180 \\
\hline 7 & 75 & 70 & 5625 & 4900 & 5250 \\
\hline 8 & 76 & 73 & 5776 & 5329 & 5548 \\
\hline 9 & 75 & 73 & 5625 & 5329 & 5475 \\
\hline 10 & 76 & 75 & 5776 & 5625 & 5700 \\
\hline 11 & 75 & 78 & 5625 & 6084 & 5850 \\
\hline 12 & 80 & 80 & 6400 & 6400 & 6400 \\
\hline 13 & 80 & 82 & 6400 & 6724 & 6560 \\
\hline 14 & 83 & 80 & 6889 & 6400 & 6640 \\
\hline 15 & 81 & 80 & 6561 & 6400 & 6480 \\
\hline 16 & 84 & 82 & 7056 & 6724 & 6888 \\
\hline 17 & 86 & 80 & 7396 & 6400 & 6880 \\
\hline 18 & 85 & 82 & 7225 & 6724 & 6970 \\
\hline 19 & 87 & 85 & 7569 & 7225 & 7395 \\
\hline 20 & 84 & 84 & 7056 & 7056 & 7056 \\
\hline Sum $=$ & 1532 & 1513 & 118404 & 115271 & 116697 \\
\hline Rata2= & 76.6 & 75.65 & 5920.2 & 5763.55 & 5834.85 \\
\hline
\end{tabular}

Setelah dilakukan serangkaian uji tes normalitas dan uji linieritas, dimana didapat hasil data Media Pembelajaran berbasis IT dan data prestasi belajar berdistribusinormal, dan hubungan antara dua variabel tersebut adalah linier.Hasil uji coba tersebut, sebagai syarat dalam melakukan analisis korelasional dengan rumus product moment. Data-data diatas merupakan tabulasi data dari dua variabel, yaitu: variabel $\mathrm{X}$ adalah media berbasis IT dan Y adalah prestasi belajar fiqih siswa MI. data X setelah dijumlah keseluruhan adalah 1.532 dengan rata-rata 76,6; data $\mathrm{Y}$ jumlah keseluruhan 1.513 dengan rata-rata 75,65. Kemudian masing-masing variabel dikuadratkan, di dapat hasil $\mathrm{X}^{2}$ 111,404 dengan rata-rata 5920,2; sedangkan $\mathrm{Y}^{2}$ didapat jumlah 115. 271, dengan rata-rata 5763,55. Data $\mathrm{X}$ dan Y dikalikan, sehingga di dapat nilai 116.697; dengan rata-rata 5834,85 . Dari data tabulasi di atas kemudian dimasukkan ke dalam rumus korelasi product moment 


$$
\begin{aligned}
& 116697-\underline{(1532)(1513)} \\
& r_{x y}=\sqrt{\left\{\begin{array}{r}
118404-\left(\begin{array}{c}
(1532)^{2} \\
20
\end{array}\right.
\end{array}\right\}\left\{\begin{array}{c}
20 \\
115271-(1513)^{2} \\
20
\end{array}\right\}} \\
& 116697 \text { - } \\
& \text { (2317916) } \\
& =\frac{20}{\sqrt{\left\{118404-\frac{2347024}{20}\right\}\left\{115271-\frac{2289169}{20}\right\}}} \\
& =\frac{116697-115895,8}{\sqrt{\{118404-117351,2\}\{115271-114458,45\}}} \\
& =\frac{1052,8)\}\{812,55\}}{\sqrt{\{}} \\
& \text { 855452,64 } \\
& =\frac{801,2}{924,906828} \\
& =0,866249416
\end{aligned}
$$

Dari perhitungan di dapat $\mathrm{r}_{\mathrm{xy}}=0,866$.sedangkan untuk jumlah $\mathrm{N}=20 \mathrm{r}$ tabel $\left(\mathrm{r}_{\mathrm{t}}\right)$ dengan taraf signifikasi 5\% adalah $r_{t}=0,444$. Sehingga $r_{x y}=0,866>r_{t}=0,444$. Untuk $r$ tabel dengan taraf signifikasi $1 \% \mathrm{r}_{\mathrm{xy}}=0,866>\mathrm{r}_{\mathrm{t}}=0,561$.

Berdasarkan hasil analisis yang menunjukkan bahwa $r_{x y}$ baik pada taraf siginifikasi $5 \%$ maupun taraf signifikasi $1 \%$ tetap $\mathrm{r}_{\mathrm{xy}}$ lebih besar dari $\mathrm{r}$ tabel. Apabila perhitungan korelasional lebih besar dari pada $r$ tabel, bisa dikatakan hipotesis yang bersifat positif bisa diterima.Sehingga Hipotesis yang diajukan penulis $\mathrm{H}_{0}$ : media pembelajaran berbasis IT berpengaruh terhadap prestasi belajar Fiqih Siswa MI di Kabupaten Sragen, bisa diterima kebenarannya. Sedabngkan $\mathrm{H}_{1}$ : Media Pembelajaran Berbasis IT Tidak Berpengaruh Terhadap Prestasi Belajar Fiqih Siswa MI di Kabupaten Sragen, tidak diterima kebenarannya.

Penggunaan media masih cukup besar dalam mempengaruhi hasil belajar Siswa hal ini juga sesuai dengan pendapat Nur'aini Agung Wijaya (2008), masalah yang diangkat adalah seputar pemanfaatan CD sebagai media pembelajaran untuk meningkatkan ketrampilan membaca huruf Hiragana. Terutama media yang bersifat aplikatif dan mendukung pembelajaran tuntas mandiri. Media berbasis IT, terutama komputer memungkinkan siswa belajar sesuai dengan kemampuan dan kecepatannya dalam memahami pengetahuan dan informasi yang ditayangkan. 
Penggunaan komputer dalam proses belajar membuat siswa dapat melakukan kontrol terhadap aktivitas belajarnya. Penggunaan komputer dalam lembaga pendidikan memberikan keleluasaan terhadap siswa untuk menentukan kecepatan belajar dan memilih urutan kegiatan belajar sesuai dengan kebutuhan.Kemampuan komputer untuk menayangkan kembali informasi yang diperlukan oleh pemakainya, yang diistilahkan dengan "kesabaran komputer", dapat membantu mahasiswa yang memiliki kecepatan belajar lambat. Dengan kata lain, komputer dapat menciptakan iklim belajar yang efektif bagi mahasiswa yang lambat (slow learner), tetapi juga dapat memacu efektivitas belajar bagi mahasiswa yang lebih cepat (fast learner), (Heinich dkk, 1996:103).

Disamping itu, komputer dapat diprogram agar mampu memberikan umpan balik terhadap hasil belajar dan memberikan penguatan (reinforcement) terhadap prestasi belajar mahasiswa.Dengan kemampuan komputer untuk merekam hasil belajar pemakainya (record keeping), komputer dapat diprogram untuk memeriksa dan memberikan skor hasil belajar secara otomatis.Komputer juga dapat dirancang agar dapat memberikan preskripsi atau saran bagi siswa untuk melakukan kegiatan belajar tertentu.Kemampuan ini mengakibatkan komputer dapat dijadikan sebagai sarana untuk pembelajaran yang bersifat individual (individual learning). Kelebihan komputer yang lain adalah kemampuan dalam mengintegrasikan komponen warna, musik dan animasi grafik (graphic animation). Hal ini menyebabkan komputer mampu menyampaikan informasi dan pengetahuan dengan tingkat realisme yang tinggi.Kelebihan ini menyebabkan program komputer sering dijadikan sebagai sarana untuk melakukan kegiatan belajar yang bersifat simulasi.Lebih jauh, kapasitas memori yang dimiliki oleh komputer memungkinkan penggunanya menayangkan kembali hasil belajar yang telah dicapai sebelumnya.Hasil belajar sebelumnya ini dapat digunakan oleh siswa sebagai dasar pertimbangan untuk melakukan kegiatan belajar selanjutnya.

\section{Kesimpulan}

Dari Hasil Perhitungan Data bisa diambil kesimpulan bahwa: (1) Hasil uji normalitas variabel media pembelajaran berbasis IT dan variabel prestasi belajar fiqih berdistribusi normal, (2) hasil uji linier antara variabel media pembelajaran berbasis IT dan variabel prestasi belajar fiqih berifat linier, (3) Penggunaan media 
pembelajaran berbasis IT berpengaruh terhadap prestasi belajar Fiqih pada siswa kelas 5 MI, karena data menunjukkan $r$ hitung lebih besar dari pada $\mathrm{r}$ tabel; $\mathrm{r}_{\mathrm{xy}}=0,866>$ $r_{t}=0,444$.pada taraf signifikasi $5 \%$, dan $r_{x y}=0,866>r_{t}=0,561$ pada taraf signifikasi $1 \%$. Diharapkan setelah penelitian ini agar: (1) penggunaan media yang berbasis teknologi di tingkat MI di kabupaten Sragen bisa dikembangkan, (2) adanya pelatihan ataupun KKGMI yang secara khusus membahas tentang pengembangandan pembuatan media yang menarik, up to date, fleksibel dan low cost, (3) Adanya evaluasi dalam penggunaan media berbasis IT pada proses KBMdi kelas sebagai bahan acuan untuk mengembangkan media pembelajaran itu sendiri.

\section{Daftar Pustaka}

Arsyad, Azhar.2011. Media Pembelajaran.Jakarta:Raja Grafindo.

Azwar, saifuddin.2011. Sikap Manusia Teori dan Pengukurannya.

Yogyakarta: Pustaka Pelajar.

Dali, Zulkarnain. 2017. Manajemen Mutu Madrasah. Yogyakarta:Pustaka Pelajar

Dirjen Pendidikan Islam.2015.Buku Siswa Fikih pendekatan Saintifik Kurikulum 2013. Jakarta;Kementrian Agama

Heinich.dkk. 1996.Instructional Technology and Media for Learning . New Jersey:Prentice Hall Englee Woods Cliffs.

Juwita, Dwi Runjani.2018. Pendidikan Akhlak Anak Usia Dini di Era Milenial.AtTajdid:Jurnal Ilmu Tarbiyah 7 (2), 282-314.

Nuraini Agung S Wijaya.2008.Pemanfaatan Compact Disc dalam upaya Peningkatan ketrampilan membaca huruf hiragana pada Siswa SMA Negeri 5 Surakarta.Tesis. Surakarta: UNS.

Rusman dkk.2011. Pembelajaran Berbasis Teknologi Informasi dan Komunikasi. Jakarta:Raja Grafindo

Sanaky.Hujair.2015. Media Pembelajaran Interaktif-Inovatif. Yogyakarta: Kaukaba

Setiawan, Nasrul. 2018. Permasalahan Data Tidak Berdistribusi Normal.https://statistikceria.blogspot.com (diunduh Maret 2018)

Sugiyono.2008. Metode Penelitian Kuantitatif Kualitatif dan R \& D. Bandung:CV Alfabeta. 